\title{
Leisure, tourism and conservation units: aspects of environmental management in the state park of the dunes of natal-RN/Brazil
}

\section{Introduction}

The present study proposes to make a cut in the evolution of leisure and tourism, with the appropriation of nature as a scenario for the development of these activities, presenting a case study in the Dunas de Natal State Park, belonging to the state of Rio Grande do Norte/ Brazil. The analyzes will be based on environmental management related to a conservation unit as a natural entertainment establishment.

In order to do so, the objective is to analyze the relationship between leisure, tourism and appropriation of natural aspects for entertainment activities, drawing the main leisure options developed in the conservation unit and the public use of the Parque das Dunas as a natural equipment for leisure practice by tourists and local people.

As for the methodological aspects, an analysis was made on leisure, tourism and environmental management, through a case study with a spatial clipping of the Valentine's Woods, which is the extension of the conservation unit of the Parque das Dunas (Natal/RN) to public use. The research consists of a bibliographic survey, analysis of the Management Plan and empirical research. It is a qualitative research that used an on-site visit, non-participant observation and semistructured interview that served as a basis for the reflections discussed.

\section{Christmas dunes state park/RN}

The conservation unit under study is recognized as an important leisure tool of the city of Natal/RN, located in the northeast region of Brazil, attracting tourists, researchers and local population for its recognized environmental value. The park has an estimated value as a natural heritage, and is also an important tourist attraction because of its relevance to the local scenery. In the meantime, Oliveira et al. ${ }^{1}$ reflect on the fact that people began to look for destinations closer to nature with the pretense of disconnecting themselves from the hectic day-to-day of big cities.

In this way, it has a natural and built structure, presenting equipment that favors the visitation of the local population and tourists. Raimundo and $\mathrm{Sarti}^{2}$ highlight the new aspirations involving leisure and tourism, having as a longing for the big cities, more options that favor the contact of the man with the natural elements.

Among the main attractions for visitors to the park are: recreation sector, visitation center, exhibition hall, space for environmental education workshops, lake, health sector, recreation area, mother earth house, amphitheater, playgrounds, picnic area, hiking trails, environmental control station, play area, jogging track.

The mother earth house is a public sculpture that became part of the collection of the park since the year 2003, built to symbolize the planet earth and raise the imagination of children, young people and adults who play spontaneously in the dependencies of the structure, considered as Mother Nature. In the surroundings, there is the workshop of environmental education and arts, being possible to
Volume 3 Issue I - 2019

Josemery Araujo Alves
Brazil Department of Tourism, Federal University of Campina
Grande, Brazil

Correspondence: Josemery Araujo Alves, PhD in Natural Resources at the Federal University of Campina Grande (UFCG) sandwich training at the University of Lisbon (Ulisboa), Master's degree in tourism from the Federal University of Rio Grande do Norte (UFRN) and a degree in tourism from the State University of Rio Grande do Norte (UERN), Lecturer at the Department of Tourism of UFRN/Brazil, Email josemeryalves@hotmail.com

Received: January 08, 2019 | Published: January 29, 2019

involve the children in the world of the imagination and the artistic medium through the production of handmade pieces that cultivate and teach about the valorization of the natural resources. Grimm et al. ${ }^{3}$ corroborates the importance of involving human beings with the natural aspects to reflect on the integration of man and nature, in a living relationship with the ecosystem, customs and local history, by the involvement of the tourist in matters related to the conservation of the environment.

Verified by means of on-site observation that the Grove receives a captive number of local visitors, and that the children are the highest goers. This can be attributed to the difficulties of finding green spaces in the city that allow greater interaction with the environment, allowing children to experience intense contact with nature and playfulness. It is possible to hold picnics, birthdays and celebrations, always meeting the local requirements and standards. One option that awakens children's enthusiasm is the children's playgrounds in the midst of the Atlantic Forest.

According to the data collected, the space has a diversified schedule, including the possibility of making interpretive trails, being divided into three options according to the degree of effort: Perobinha, Peroba and Ubaia Doce. The trails are guided and happen with scheduling of an estimated number of people, not exceeding the carrying capacity allowed in each route. The trails vary between $800 \mathrm{~m}$ and $4,400 \mathrm{~m}$ in length, providing visitors with contact with rich flora and fauna, lush look and panoramic viewpoints.

It is worth mentioning that the opening of a conservation unit for tourist visitation can cause a series of impacts, therefore it is necessary to understand that tourism can generate advantages from the economic point of view, but it can also imply in environmental degradation, loss of identity local, among other possible negative impacts Brazil. ${ }^{4}$ In this way, an active, conscious and faithful management of environmental standards becomes essential, avoiding greater impacts on the natural environment.

According to interview reports, education and environmental awareness are strategies adopted by the park administration, in order 
to reduce the risk of environmental degradation. Explanatory plaques, prohibition of feeding of animals, policy to encourage recycling, concern for the adequate destination of pollutants produced, among other measures are included. The existence of solid waste separation containers are found in all areas of the Forest.

In the dependencies of the Dunas de Natal State Park is the environmental control post, in which besides the conservation unit, they inspect the other green areas of the city. The presence of the environmental battalion in the facilities of the park inhibits the action of vandals and degrading agents, due to permanent patrolling. For Marinho ${ }^{5}$ adventure activities carried out in nature require a careful look capable of valuing both the quality of the practice and the conservation and environmental education and the personal and social developments inherent in them.

The area has cultural attractions that blend with the natural aspects, such as the sound of the forest project that prioritizes musical and theatrical performances, valuing artists and allowing the population and tourists a diversified program, happening in the amphitheater of Brazil. In this place also happen children's shows, with presentation of pieces, staging of characters and musicals for children.

It has an effective staff of employees and trainees from various areas, among them, students of tourism. These trainees develop a significant work in the premises, contributing to the environmental management actions developed, being responsible for hospitality and hospitality, guided tours, environmental education workshops, sustainability practices, arts and recycling, lectures, cultural and festive programming.

According to information collected locally, the large percentage of the public is a local population, but national and international tourists also have a captive presence primarily on weekends, high season periods and important events. According to data collected, there is a significant difference in the perception and appreciation of the space in relation to the tourists and the autochthonous population. As mentioned, tourists show greater appreciation and recognition of space as a natural resource, and are also more aware of the park's management policy and standards.

In this context, it is fundamental to foresee more dynamic relationships that prioritize leisure and conservation of the natural space, focused on awareness and socio-environmental sustainability Gomes et al. ${ }^{6}$

It is worth highlighting the significance of Parque das Dunas for the local population, besides being considered as important tourist attraction and research target of many researchers who are interested in the rich biodiversity found in the place. With the structuring and opening of the Bosque dos Namorados for public use it became possible to develop leisure and tourism activities in the middle of the Atlantic Forest, being recognized for its intrinsic value of interaction with nature.

Considering the significance of this space as a natural patrimony of the city of Natal/Brazil, it is necessary to focus on environmental management actions that may entail the preservation of the available resources and conservation practices, in order to keep the characteristics of the park intact.

\section{Conclusion}

It is known that many landscapes are transformed by human action to meet the longings of leisure and tourism. Devastated woods, buildings in the middle of the natural environment, attacking the fauna and flora of the place, incentive to activities with massive tourist flow, disrespecting the limits of the capacity of loading ecosystems. Aware of these aspects, a series of preventive and maintenance measures are taken by the management of the Dunas State Park, aiming at minimizing possible negative impacts from the visit to the Bosque dos Namorados, such as lectures and recycling workshops, environmental education, destination policy adequate waste, reuse of water, implementation of entertainment structure taking advantage of the natural resources arranged in the park.

However, it is known that a conservation unit that is open to visitation must constantly carry out load-carrying surveys and studies that allow measuring the real impacts of human presence. Undoubtedly, the Dunas de Natal/RN State Park is an important natural resource in the midst of the urban environment and unique characteristics in Brazil, increasing even more the responsibility for preserving this incalculable environmental wealth, and cannot be ignored the associated management rules the environmental management of this important conservation unit.

The Bosque dos Namorados is a space of public use and for its significance in the environmental context, it should try to reconcile in the best possible way the requirements of the Management Plan linked to the principles of sustainability, aiming to remain with favorable conditions of reception of the visitors, but having as the main focus is the maintenance of this relevant environmental resource registered by UNESCO.

\section{Acknowledgments}

None.

\section{Conflicts of interest}

The author declares there is no conflicts of interest.

\section{References}

1. Oliveira JP, Freitas IN, Nobrega WRM. Participação comunitária no desenvolvimento do turismo: um estudo no Parque Estadual da Pedra da Boca PB. Holos. 2018;6(34):151-170.

2. Raimundo Sidnei, Sarti Antonio Carlos. Parques urbanos e seu papel no ambiente, no turismo e no lazer da cidade. Raimundo. 2016;6(2):3-24.

3. Grimm, Isabel Jurema, Loose, et al. Turismo, comunicação e sustentabilidade: reflexões e possibilidades para educação ambiental. Est Pes Tur Curitiba. 2013;2:26-42.

4. Brazil. Ministry of Tourism. General Coordination of Regionalization. Program of Regionalization of Tourism - Routes of Brazil: Tourism and Sustainability/Ministry of Tourism. National Secretariat of Tourism Policies. Department of Structuring, Articulation and Tourism Planning. General Coordination of Regionalization. Brasilia; 2007.

5. Marinho Alcyane. Lazer, meio ambiente e turismo: reflexões sobre a busca. Licere Belo Horizonte. 2007;10(1).

6. Christianne Luce Gomes, Mirleide Chaar Bahia, Rodrigo Elizalde, et al. Lazer, sustentabilidade e meio ambiente na América Latina: Problematizações E Desafios. Dossiê Lazer e Meio Ambiente. 2014;1(3). 